\title{
Cruzando Fronteiras: \\ narrativas de transnacionais tornando-se professores de Língua Jnglesa no México
}

\author{
Crossing Borders: Stories of transnationals BeComing \\ ENGLish language TEACHERS IN MeXico
}

\author{
Irasema Mora Pablo* \\ M. Martha Lengeling** \\ Nora Margarita Basurto Santos***
}

Resumo: Os dados apresentados neste artigo provêm de um estudo realizado ao longo de dois anos, que examina as vidas de imigrantes transnacionais de adultos jovens, cujas famílias residem há vários anos nos Estados Unidos, sempre mantendo estreitos vínculos com seu país de origem, o México, até que decidiram ou foram forçados a voltar. Estes participantes aprenderam inglês como filhos de imigrantes mexicanos nos Estados Unidos. Por meio de uma abordagem narrativa, os resultados mostram como esses estudantes constroem suas identidades através de sentimentos ambivalentes em relação a ambos os países e como esta construção identitária molda seus interesses em tornarem-se professores de Inglês ou mesmo rejeitarem a língua,

* Doctorate in Applied Linguistics from the University of Kent in England (2012). Coordinator of the Master's of Applied Linguistics of English Language Teaching at the Language Department of the Universidad de Guanajuato in Mexico. Contato: i.m.pop@hotmail.com.

** Doctorate in Language Studies from the University of Kent in England (2007). Professor at the Universidad de Guanajuato and she is also the Editor of MEXTESOL Journal. Contato: lengeling@hotmail.com.

*** Doctorate in English Language Teaching and Applied Linguistics from Warwick University in England (2010). Professor at the Universidad Veracruzana where she is the Director of the School for Foreigners. Contato: nbasurto@uv.mx. 
a ponto de esquecerem a língua que aprenderam nos Estados Unidos. Aparentemente, as experiências transnacionais de moradia em dois países foram fundamentais para a construção de suas identidades, definindo quem são e o que querem ser. Este trabalho sugere que indivíduos trasnacionais detêm um importante capital cultural e linguístico, que usam a seu favor, a fim de se integrarem em seu próprio país de origem.

Palavras-chave: Transnacionais. Identidade. Narrativa.

\begin{abstract}
The data in this article come from a two-year study that examines the transnational immigrant lives of young adults whose families resided for a number of years in the United States, always maintaining close ties to their country of origin, Mexico, until they decided or were forced to return. These participants acquired English as children of Mexican immigrants in the United States. Using a narrative approach, findings depict how immigrant students shaped their identities through ambivalent feelings towards both countries and how this identity construction shaped their interest in becoming English teachers or rejecting the language to the point that they forgot the language they had learned in the United States. Their transnational experiences of living in and between two countries appeared to be at the forefront of their construction of identity, defining who they are and who they want to be. This work suggests that transnationals possess an important cultural and linguistic capital that they use to their advantage in order to fit in in their own country of origin.
\end{abstract}

Keywords: Transnationals. Identity. Narratives.

\title{
Immigration and Transnationalism
}

Transnationalism is different from immigration. Hornberger (2007, p. 326) states that "the latter involves a more permanent affiliation with the host country and separation from the home country while the former may imply no long-term intention to stay beyond what is economically necessary". This can result in transnationals feeling a transformation and becoming other to 
both home and the host national-cultural contexts (TRUEBA, 2004), leading to the development of transnational identities that might place them in ambivalent worlds or living in between.

The migratory movement of people across the American and Mexican border has been documented extensively (GUTIERREZ, 1987; LEVITT; WATERS, 2002; TRUEBA, 2004; ARRIAGADA, 2005; SMITH, 2006; WALDINGER, 2013). However, most of the literature on transnationalism has emerged in the host country, focusing on how the families adapt to the new culture and struggle to maintain ties with their country of origin. Petrón (2009, p. 115) states that: "Much has been written on the effects of Mexican immigration in the U.S., but little exists regarding the ways in which transnationals, who have returned to Mexico, have adapted to and/or transformed Mexican society and the education system". Bhatt and Roberts (2012, p. 178) suggest that it is important to research transnationalism from the perspective of the expelling countries as "we have yet to arrive at a complete understanding of the ramifications of return migration on areas of origin. In this line, authors such as Smith (2002, 2006), Petrón (2009, 2014), Brochin Ceballos (2012), and Smith and Murillo (2013) have documented the experiences these transnationals face when they return to Mexico. In particular, this present study focuses on those who return after spending most of their lives living in the United States and are at an age when they start their university studies.

As Wyman (1993) has documented, the phenomenon of immigrant families maintaining strong ties to their cultural homelands has always been a part of their history. Given its proximity to the United States, Mexico is the main expeller country in Latin America. However, in recent years and due to the economic problems in the United States and the lack of job opportunities, many immigrants have returned to their home country. According to National Institute of Statistics, Geography and Information (Instituto Nacional de Estadística, Geografía e Informática, INEGI, 2010), 350,719 people returned to Mexico in 2010, and about $48.8 \%$ of this population is between 20 to 34 years old. This means that this population returns to the homeland and starts to look for opportunities either for studying or working.

These transnationals return with a language skill that is in demand in the Mexican educational system. They are perceived as having an edge over 
their counterparts, specifically, their linguistic ability in English denotes a native-like proficiency and transnationals are immediately classified as native speakers of English, but they start experiencing a different treatment from their Mexican peers. They are usually reminded that they might look Mexican, but they are not considered Mexican, even when their command of Spanish is fine. Williams, Alvarez and Andrade Hauck (2002, p. 568) mention that "Physical appearance has been an indicator of culture, a marker of status, and an index of acculturation". Their English proficiency places them in a different status in relation to Mexicans (MORA PABLO et al., 2015), but also it reminds them that they do not belong to their country of origin, instead, they experience a sense of living in two worlds, physically living in Mexico, but longing for the life they lived in the United States.

\section{Forming Identity: Between two worlds}

For these participants, answering the question of "Do you think you feel more Mexican or more American?" is not an easy task. They have experienced living in two countries or have experienced their country of origin through their parents. In the case of transnationals, the family plays an important role in keeping close ties to their home country, by using the native language, celebrating some festividades [festivities] or keeping close contact with relatives in Mexico.

These former immigrant children start developing a sense of fragmented identity which may include feeling part of the community or feeling rejected (PETRÓN, 2009). This feeling can be underpinned by the population of the host country due to several factors: a sense of difference (mainly physical appearance), their accent that denotes they are from Mexican descendants, or the lack of economic resources that show they are in the host country struggling to survive most of the times. Learning the language of the host country becomes essential to feel part of the new community. Suárez-Orozco and Suárez-Orozco (2001, p. 104) mention that: "Learning to speak standard English is not only a way of communicating, it also becomes an important symbolic act of identifying with the dominant culture... to see language as a mere tool for communication is to miss its deep affective roots". In this sense, language becomes an important identity artifact that 
helps these immigrants to generate a sense of belonging. However, this can create a conflict between the old identity and the new (GOODENOW; ESPÍN, 1993; GOWAN; TREVIÑO, 1998). For example, "For defenders of 'correct' Spanish, Mexicans in the United States and US-born ethnic Mexicans ought to speak standard Spanish, with no interference from English, as though Mexican Spanish had been impenetrable to the linguistic and cultural influences of English" (SÁNCHEZ, 2011, p. 314).

Social identities can mean those based on groups that are a collection of individuals who perceive themselves to be members of the same social category and can even share some emotional involvement (TAIJEFL; TURNER, 1986). Their ambivalent feelings towards an American or Mexican ethnic group make it difficult to define who they are and who they want to be in the future (TANIGUCHI, 2002). Zentella (2002) discusses that the problem with "transnationals" is that their ethnic identity starts to be questioned, because they are considered "ni de aqui ni de allá" (not from here, nor from there). When in the United States, transnationals are constantly reminded that they are not part of the culture, but when returning to their place of origin (Mexico), they do not meet the expectations of this culture either (MORA PABLO, 2011). They receive the message from both sides of the border, and their identity falls in a "grey zone" where they do not feel part of any particular side, but they possess a cultural and linguistic capital that is in a growing demand in Mexico. As Murillo (1999, p. 16) states, "the modern concept of community, based on the nation-state, common language, and experience has long become incapable to gain an understanding of the fragmented and often paradoxical identities that are negotiated between worlds".

\section{Methodology}

\section{Participants}

The participants for this study are seven students (four women and three men) between the ages of 21 to 30 years. Two of the women study a BA of English Language at a university in south Mexico and three men and two women study a BA TESOL (Teaching English to Speakers of Other 
Languages) at a university in central Mexico. Both universities are large public universities in Mexico. The participants were chosen based upon the researchers' knowledge of the participants' previous experiences as transnationals and their bilingual command of English and Spanish. Both of these aspects were the basis for their selection as participants. This knowledge was obtained in our classes and they were invited to participate in the study and given a letter of consent. All are Mexicans who went back and forth from Mexico to the United States while they were growing up as children, except for one who was born in the United States. They lived in Texas, California, Illinois and Oregon for extended lengths of time while they were growing up. They returned to Mexico for personal reasons and eventually began their degree programs in the two universities. In order to protect their identity, we gave the participants pseudonyms.

\section{Qualitative research and narrative inquiry approach}

To explore their identity formation, we used qualitative research and more specifically a narrative inquiry approach. Qualitative research is "concerned with understanding behavior form actor's own frames of reference" and "tends to focus on exploring, in as much detail as possible, small numbers of instances or examples which are seen as being interesting or illumining and aims to achieved 'depth' rather than 'breadth"' (BLAXTER; HUGHES; TIGHT, 2006, p. 64-65). The actors in this research are the students and we aim to explore in detail their stories of being transnational. Concerning narrative inquiry, Webster and Mertova (2007, p. 13) mention the benefits of this approach in the following terms:

Narrative inquiry is human centred in that it captures and analyses life stories. In doing this it has the ability to document critical life events in illuminating detail, and yet also reveal holistic views, qualities that give stories valuable potential for research.

With the use of narrative inquiry we wanted to explore specific events and details of our students' life experiences and more specifically their stories of how they became transnationals. The following are the questions which guided our research: 
1) How can participants describe their experiences in both countries?

2) What opinion do they have of both countries and ways of living in them?

3) What factors influenced their acceptance or rejection of the English language that led them to become English teachers in Mexico?

\section{Techniques}

Data was collected from two techniques: student narratives and open interviews. First, the students were asked to "write their stories". The narratives were used as a basis to ask more extensive questions in the interview. The narratives also helped to provide a deeper understanding of the students' lived experiences and from there we were able to ask more specific information in the interviews. From these narratives the researchers carried out audio recorded interviews. For these interviews, a life-story approach was adopted, i.e., we drew upon an analysis concept, where we distinguished not only between the perspective of the interviewee in the past, but also the present (JAATINEN, 2007). In this article, we use the code SN to signal an extract from a student's narrative and I to signal that the extract comes from an interview.

The process of analysing the data was on-going and we worked with the narratives and the interviews transcripts at the same time. As part of the narrative analysis, we looked for similarities in the data and grouped them in a same category in order to form themes. Barkhuizen (2013, p. 11) mentions that "Thematic analyses follow the paradigmatic procedures of coding for themes, categorizing these and looking for patterns of association among them". The data used for this article is part of a larger study of return migration and their incorporation into the Mexican educational system at the university level.

Three main themes emerged from the data. We begin the presentation of the findings by discussing the participants' mixed feelings regarding their adaptation to a new culture, a new language and new people; this is what we call crossing borders, navigating between identities. Next, we discuss how participants compare their lives when being in the United States and in Mexico. Finally, we illustrate the reasons why these participants ended up becoming 
English teachers in Mexico. Transnational experiences emerge as an important aspect in their decision of becoming English teachers or not.

\section{Crossing Borders: Navigating between identities}

Respondents perceived differences between Anglo-Americans and Mexicans, first considering the physical appearance but then it was something else that told them that they were not part of this new community, as they were constantly reminded they did not belong. Noelia recalls:

Most of the girls were blonde, with blue eyes. Their hair was blonde, so, they were different, and suddenly I questioned 'Why are they like that? Why are we like this?' Genetically they were like that, and I saw my teacher, a latino's daughter, and she was so much like me, dark hair, dark brown eyes, dark skin and I asked to myself why there were so few like us. (SN)

For another participant, Lolis, these differences made her feel proud of her heritage and she embraced her Mexican ethnicity:

I felt with that sentiment of 'I'm Mexican'. I never wanted to show that I was something else, other than I was Mexican. (I)

However, physical appearance showed to be an important factor to make these participants (non) members of the community. For Lolis, her experience was different than from the rest, as her physical appearance (fair skin, blue eyes) helped her to be accepted by her classmates:

Of course, because of my physical appearance I blended in junior high school. My teachers and classmates accepted me very well. (I)

But it was not only the physical appearance that participants perceived as one of the significant factors that made them different from the Anglo-Americans, it was also the economic differences that constantly reminded them that they were new in the community, as Noelia mentions: 
Another thing that I remember so much is Halloween. It was something very sad for me because everybody was in a costume and I wanted to go and ask for candies because kids would get candies and I wanted to go with them, and they [my parents] would say 'But you need a costume and we don't have money [to buy a costume]', and I kept saying 'But I want to go. I want to be a witch, a vampire, a mummy'. $(\mathrm{SN})$

She also mentions a particular incident with a small American girl and how this made her realize that she was different from the rest of her classmates:

There was a girl that always said 'Leave me alone with my best friend'. She was American, so... I don't know if it was racial discrimination or economic discrimination. There was this brand called Liza Frank. They had some binders and stickers and stationary things and I really liked it. Then, my mom could only buy me the one-dollar stickers, and I didn't have the binder. That's why I feel I could not be part of her [the American girl's] club. I didn't have the binder. (SN or I)

The social environment and the adaptation or rejection that these participants experienced, made them see the differences between the two countries. They realized they were Mexicans and their family embraced this pride in them but at the same time they were forming their identity within the American culture.

\section{Comparing Life between Mexico and the United States}

As participants were going back and forth between Mexico and the United States, or some of them spent all their adolescence years in the United Stated without being able to return to Mexico, they were forming their own identities. This identity includes a solid proficiency and command of English, maintenance of their Spanish as L1, and switching between languages. They also learned how to live in the United States but always with the family reminding them where they came from, not allowing them to forget their Mexican heritage. For these transnationals, living in two countries taught them 
how to embrace both cultures, but also to identify those aspects that they liked from either Mexico or the United States. Samuel, one of the participants, makes a comparison between the two countries:

In the States it is more, more rapid. Everything is... you gotta be against time, as opposed to here in Mexico, it's more relaxed. It takes things step by step, as opposed to in the States. It's everything: 1, 2, 3. Let's go! (I)

For Julio, another participant, the differences between Americans and Mexicans are many, and he reveals how the community where he lived in the United States, affected the way he perceived Mexicans and his father's influence:

Here in Mexico, I feel like I'm a Mexican but I feel like I am different. In the U.S. we see Mexicans as...well, I see Mexicans as over there in my community [Chicago], as not caring about what the laws [say]. I saw Mexicans as they kept dropping out or going towards the gangs because that was my context. I saw it. I would see girls in high school or even younger being in elementary school pregnant, and joining gangs or using drugs. So my concept of Mexican, of being Mexican, was negative, but I knew I was Mexican because my parents are Mexican. I feel and felt by then Mexican. (I)

Julio even defines Mexicans in two different ways:

I take the word Mexican in two ways: either you're bad and don't like following rules, or I follow like my father does. I feel like my father is a good example of what a Mexican should be, and it's hard to find. I see my father as being the perfect Mexican, like he doesn't go out drink and say 'Viva Mexico cabrones' [long live Mexico mother fuckers] or whatever. (I)

It was of particular interest to see how Julio defines himself as Mexican, but not as any Mexican, a particular type of Mexican that deviates from the 
image he perceived in his community in the States but also when being in Mexico:

I see myself as a Mexican, but a progressive Mexican and not as a Mexican that is uh...how do you say exigiendo? [demanding] requiring the government to pay everything that the citizen wants. My father has the John F. Kennedy phrase that he does not ask about what the country is gonna give him, but what can I do to make my country better. Then I think that with true examples he does it. That's how I feel that I'm a Mexican but through that definition of a Mexican. (I)

Bertha, another participant, show how she still feels "attached" to her life in the United States:

I feel more American. I'm still faithful to the United States. My memories are from there, my way of thinking. My mom feels bad. She says: 'But you are Mexican' and I tell her: 'But I didn't grow up here'. (I)

Despite their feelings of belonging to two different cultures, these participants at first were taken to the United States by their parents, and inserted into a new culture. However, returning to Mexico was a difficult decision for most of them, as they were already in the process of coming to terms with their ambivalent feelings as transnationals settling down in the United States.

\section{Coming Back to Mexico: Redefining identity}

Participants reported their reasons to return to Mexico. Some of them could not continue living in the United States due to their migratory status, and some others had to come back for family reasons. Lolis recalls the moment when she told her mother that is was time to return to Mexico to pursue university studies: 
My mother told me that she supported me a hundred percent 'You go. We are going to keep working and we are going to send you money so you can study at the university'. (I)

For another participant, Bertha, coming back to Mexico was not her decision, but her family's. She was about to start high school and she had to return to Mexico, after living in the United States for fourteen years:

I left Mexico when I was two years old, and I was in the States for fourteen years. When I was sixteen, my grandfather got sick, and my grandmother died of cancer, so, my father said: 'Everybody is dying and you don't know them. We are going back to Mexico'. At the beginning I couldn't believe it, because my dad, every December threatened us with the same, but when I saw the plane ticket, I realized this time was true. (I)

For most of these participants, their adaptation process took some time and they even changed their behavior and the way they socialized among Mexicans:

I became more anti-social. There were people telling me 'You speak funny', 'Your Spanish is mocho [corrupted]' and I was like 'Aghh, leave me alone!' but then I started to gain confidence again. It was a long process. (I)

In the case of Lolis, she did not want to reveal she had lived in the United States because she felt that she was going to be excluded from her new social group in Mexico:

I arrived here at the university and I felt like 'Should I say I come from Texas? No, I'd better say nothing'... because I felt that if I said something, they would say: 'Ay, she is showing off'. I wanted to avoid many things, and I said 'If I say I come from Coatepec, because I studied until fifth semester there, three years ago... but they are going to say that no, that someone studied there and they don't know me... 
Well, I'll say that I come from there [Texas] that I'm Mexican, a hundred percent', because I have always been. I'm Mexican.' (I)

For some other participants, being back in Mexico, influenced their language choice. This is the case of Julie:

(When we returned to Mexico), we didn't speak English anymore. Most of my conversations were in Spanish. We didn't have the need to speak in English and [my parents] saw it in that way. I had a hard time in junior school, in high school and university. It was torture for me to have English classes. And I told my parents 'Why? Why didn't you keep on practicing [English] with me?' and they said 'Ay mija [daughter], we were here and what were we going to use English for?'(I)

As a result, Julie started to feel rejection towards English:

I'm one of them. I have always felt rejection towards English. It is very difficult for me. I don't like it. I don't think it is a pretty language, and I have always said it. [And people tell me] 'Look, English is easier than Spanish. Its grammatical structure is very simple' and I know, but...I'm part of those types of students who are desidiosos [uncaring]. (I)

All these experiences had an impact on the participants when deciding what to do with their professional lives. As Sánchez (2007, p. 279) suggests, "[transnationals] are afforded an entirely different host of socio-cultural resources from which to draw, including but not limited to the ways they speak, construct identity and develop their worldviews".

\section{Becoming an English Language Teacher...or not?}

After a careful analysis of the data, it became apparent that the participants' experience of living in the United States and their having to return to Mexico played an important role in their decision and/or their 
family's decision to choose what to study or what they wanted to pursue as their future careers. The following quote is a clear example of how their families influenced their choices regarding their university studies, as in the case of Ivan:

...most of my family, on my dad side, they are teachers from the Normal [teachers' college] so I didn't want to be like them. They entered the Normal when you didn't have to go to [senior] high school when from secondary school you could enter the Normal and I had my doubts about them. And I was like wow, then they didn't have preparatory level school, how can they like go into college you know and get a degree, so I had my doubts about that and they were like: Yeah, you are the first one who can actually go to college from the family and go to the school we went' to but I didn't want to. (I)

For most of our participants' family members, it was important for their children to have the opportunity to study an undergraduate program since they themselves had had little access to education in Mexico. In fact, the vast majority of our participants' parents and family members did not study senior high school or university. The fact that they lacked opportunities to go to the university seemed to be main reason to encourage their children to further their formal education. Lolis, one of our participants, explained that:

...my mom told me that she supported me 100\%. She said: 'You should go back to Mexico. My sisters will also support you. We are going to continue working and will send you money so that you can study university there'. (I)

Living in the United States represented many good opportunities for our participants and their families. However, given their legal situation in the country, it also posed several constraints. For example, one of the main problems faced had to do with having access to higher education. Therefore, one of the options their families thought of was that their children should come back to Mexico even if they had to stay in the United States and help them somehow from there. 
Most of our participants expressed that they wanted to study "something" at university but they were not sure what it was at that moment:

I wasn't really sure what to do with my life. I knew I wanted to become a professional and do something like get a career or do something for a living but I really wasn't sure what to do. (SN)

For some others, when the moment came to decide whether to pursue or not university studies, they were advised by their parents or other members of the family. This happened to Samuel:

I came here to study at the university, but I didn't know what, but then I took a year off. Then I started to think: 'Well, the only thing that I'm good at is in school and I feel comfortable in school'. Then my aunt told me 'Well, why you don't just be a teacher.' My aunt noticed that I was able to help my cousins and the local people around there with math and other subjects, like 'Pos eres bueno' [Well, you're good] so you should just go for a teacher. (I)

Although both the participants and their families could appreciate that having access to university education represented a better life in Mexico, it was not easy for them to decide what exactly they could or want to study. In fact, as some of them had already lived in the United States for a long time, studying to become an English teacher did not seem a good option, as was the case for Lolis:

Well, in fact they [my parents] never thought of a BA in English as an option for me. Besides, I didn't know there was a BA in ELT [English Language Teaching] and I don't know but I have always said I am a practical person, of practical decisions and so is my family. So, they would say: Why are you going to study a BA in English Language Teaching if you can learn the language in a course. You can learn the language, but you don't have to study a BA. You can take a course. You don't have to spend four years at a university to learn just English. (I) 
For some of the participants and their families, learning a foreign language should not take so many years of university studies. Any foreign language could be learnt by taking just a course. They did not see why four years was needed to just learn English. It seems that they thought that their children already knew enough English since they had spent part of their lives in a country where they had had to study in English. However, Samuel explained how this experience represented both an advantage but also a disadvantage. He explained why he did not feel his knowledge of English was enough to become an English language teacher:

... an advantage could be that I lived in the States twenty years, so twenty years is good because I reached two years of university in English. So in a way I'm good in English, but also I've seen throughout the years, I've seen that even though you were born there, it doesn't mean you are the greatest [...] I believe that some Mexican students that learn English have a greater advantage over me cause I learned it through acquiring the language, so grammar was not an important factor in my learning of English or my acquiring of English. I don't remember in my English classes ever talking about big grammar points. I feel like English was learning vocabulary or chunks, or things like that [...] A disadvantage would be that maybe being more in Chicago, yeah I can have a greater ability to speak or vocabulary, but regarding grammar I cannot explain most of the grammar points that some of the Mexican students can...(I)

Whereas for some participants' families, studying university to become English language teachers was not a good option, for others becoming an ELT was a good idea. They even helped and encouraged their children to enroll in a BA in English at a Mexican University, as in the case of Bertha:

When I was about to finish senior high school my mom called the Language Department to ask for information about English or other foreign languages and then they told her about the BA in English and they gave her all the information to study that and then my dad said: 'Yes, you have to go. I'll support you'. (SN) 
It was also interesting to realise how some of these participants' experiences of having to learn English as a result of their moving to live in the United States, helped them decide to use their own skills as foreign language learners and use them to shape their future professional careers. Samuel explains this:

I think that helped me in the sense where, the stuff that I teach I bring my own experience, to help my students being motivated and also to help them to learn the language in a way that, not as I learned it, but to help them well facilitate the learning, making it easier to them to learn the language. (I)

Another example shows how some participants decided to take advantage of the English they had learnt or acquired while they lived in the United States. They decided to "give it a shot" in trying to find out what to they could do for their future careers. Ivan's excerpt expresses this clearly in the following:

I was like yeah I know English and since the experiences I've had helping my classmates I was like it's maybe something I wanna do and so yeah I took the exam and I passed, and yeah at first I was like well, let's give it a shot you know and see what it's like and throughout the course of the BA throughout the phases first, second, third semesters I figured out that yeah it is something I really wanna do, something I feel good with. It's something that I can identify myself with, something I can do for a living and yeah I think it was a good decision. (I)

Finally, it was interesting to note how some of our participants "fell into the profession" even before they finished their BA in English. As they already had a good level of English, they were given the opportunity to do some teaching to help a teacher. They ended up having a job as EFL teachers in high school, as Ivan explains:

I think it was in first or second semester I had the opportunity to give some tutor sessions to the students at the school where I graduated 
from preparatory level school so then there was a conflict between the English teacher and some students. Also at that time the teacher was offered another job so he left the school and the administrative people at the school they saw that I was helping the students out a little bit and that they [students] could understand me so after that I got called in: Hey do you want a job? Do you wanna work and I'm like: 'Yeah, I'll do it' and that's how I got my first job. (I)

Ivan did not plan to become a teacher but eventually he decided to become a teacher and even realized he enjoys being a teacher. He seemed to eventually embrace being a teacher.

\section{Discussion}

The data from this research shows how there is a new emerging group of teachers in the EFL profession in Mexico. As it was mentioned before, participants were studying a BA in TESOL but they were already in-service teachers who taught English at different levels, from kindergarten to university. These teachers are transnationals who have lived for a number of years in the United States and grew up in a bilingual context where they went back and forth from Mexico to the United States. For a variety of reasons they returned to Mexico and they "fell into the job of teaching" EFL (LENGELNG, 2007) due to their high proficiency of English. They did not plan to become teachers and their career entry was somewhat casual.

Their decision to study a degree program in EFL teaching was influenced mainly by their parents and other family members. These people played an important role in this decision making, by often recommending that they take advantage of their linguistic and cultural skills. In essence, these skills became linguistic and cultural capital and opened the doors to their present and future as teachers. These transnationals eventually realized that they enjoyed teaching English and embraced this decision to stay in the job once they became teachers. They also felt they could be good at teaching English because of their language expertise and cultural knowledge. Their role becomes extremely important in Mexico due to their linguistic capital, as they poses a cultural and linguistic capital that is in demand in Mexico and 
more English teachers are needed. Potentially, they can become role models for those learners who might have difficulties while learning the language, as they see them as Mexicans who learned the language and they can see this is possible.

Regarding their identity, they constantly negotiated their identity depending on where they were situated. Their identity process is based upon their lived experiences in two countries: the United States and Mexico. At times they did not feel they fitted completely into a specific national identity, however, they also created a hybrid identity of being bilingual and transnational. They continually negotiated their identities and emotions and showed flexibility as individuals. Through time the participants seemed to resolve some problems of identity, such as feeling more American or more Mexican at different moments of their lives, or even feeling identified with a particular culture and feeling nostalgic for those days they lived in the United States. The constant movement between the two countries, and the contact with their family in their home country, allowed them to create their own images of what it means to be an American or a Mexican, and they can even relate to these images, sometimes placing one over the other. Their identity as individuals has been shaped by their experiences in both countries. Their diverse experiences and rich trajectories have shaped who they are and who they want to become. In one particular case, bad experiences in the United States created a negative image in one of the participants to the point that she hated the language and avoided to speak in it.

Concerning their teacher identity, they bring a number of positive attributes as teachers because of their lived experiences as transnationals. Professionally they do not fit into the traditional paradigm of native and non-native speakers, yet this is not the focus of this article. What is evident and of great importance is that these teachers are a new generation of professionals who have a definite position within the work force of EFL teachers in Mexico. They also seem to expand or cross the borders of the dichotomy of labels we have created for years for English teachers such as native and non-native, foreigners, nationals, locals, among others. 


\section{Conclusions}

The present study has showed us how transnationals shape their identities through ambivalent feelings. There are periods of rejection and feelings where the participants identify themselves with either country of the United States or Mexico because each of these countries have given them a home at different parts of their lives. This, in turn, provides them with a sense of belongingness at different parts of their lives. They seem to connect to these experiences in both countries.

Yet, it should be mentioned that returning to Mexico also implied new challenges for the participants as well as new ways of adapting to one country that in theory could be considered as their home country. Often this home country did not recognize them entirely as part of the local community and even questioned their identity. This became a period of struggle for them because they began a new adaptation process and their linguistic and cultural capital served as a tool to be used to their advantage. Becoming English teachers is a way for them to become part of a social group in which they are definite members and they can provide something they feel they are good at which is the use of language and culture. In the end they adjusted themselves and became teachers, which provided them with a positive teacher identity.

\section{References}

ARRIAGADA, P. A. Family context and Spanish use: A study of Latino children in the United States. Social Science Quarterly, v. 86, n. 3, p. 599-619, 2005.

BRAKHUIZEN, G. (Ed.). Narrative research in applied Linguistics. Cambridge: Cambridge University Press, 2013.

BHATT, W.; ROBERTS, B. R. "Forbidden return”: Return migration in the age of restriction. Journal of Immigrant and Refugee Studies, v. 10, p. 162-183, 2012. 
BLATER, L.; HUGHES, C.; TIGHT, M. How to research. Maidenhead: Open University Press, 2006.

BROCHIN CEBALLOS, C. Literacies at the border: Transnationalism and biliteracy practices of teachers across the US-Mexican border. International Journal of Bilingual Education \& Bilingualism, v. 15, n. 6, p. 687-703, 2012.

GOODNOW, C.; ESPÍN, O. M. Identity choices in immigrant adolescent females. Adolescent, v. 28, p. 173-184, 1993.

GOWAN, M.; TREVIÑO, M. An examination of gender differences in Mexican-American attitudes toward family and career roles. Sex Roles: A Journal of Research, v. 38, p. 1079-1094, 1998.

GUTIERREZ, R. A. Unraveling America's Hispanic past: Internal stratification and class boundaries. AZTLAN, v. 17, n. 1, p. 79-101, 1987.

HORNBERGER, N. H. Biliteracy, transnationalism, multimodality, and identity: Trajectories across time and space. Linguistics and Education, v. 18 , p. 325-334, 2007.

INSTITUTO NACIONAL DE ESTADÍSTICA, GEOGRAFÍA E INFORMÁTICA - INEGI. 2010.

JAATINEN, R. Learning languages, learning life-skills: Autobiographical reflexive approach to teaching and learning a foreign language.

New York: Springer, 2007.

LENGELING, M. M. Falling into the EFL Job in Mexico. MEXTESOL Journal, v. 31, n. 2, p. 45-53, 2007.

LEVITT, P.; WATERS, M. C. Introduction. In: LEVITT, P.; WATERS, M. C. (Eds.). The changing face of home: The transnational lives of the second generation. New York: Russell Sage Foundation, 2002. p. 1-30.

MORA PABLO, I. The 'native speaker' spin: The construction of the English teacher at a language department at a university in central Mexico. PhD unpublished dissertation, University of Kent, 2011. 
MORA PABLO, I. et al. Transnationals becoming English teachers in Mexico: Effects of language brokering and identity formation. GIST Education and Learning Research Journal, v. 10, p. 7-28, 2015.

MURRILLO, Jr., E. G. Mojado crossing along neoliberal borderlands. Educational Foundations, v. 13, p. 7-30, 1999.

PETRÓN, M. Transnational teachers of English in Mexico. The High School Journal, p. 115-128, Apr./May 2009.

PETRÓN, M. Borderland epistemologies and the transnational experience. GIST Education and Learning Research Journal, v. 8, p. 137-155, 2014.

SÁNCHEZ, M. E. Pocho en español: The anti-pocho pocho. Translation Studies, v. 4, n. 3, p. 310-324, 2001.

SÁNCHEZ, P. Cultural authenticity and transnational youth:

Constructing a meta-narrative across borders. Linguistics and Education, v. 18, p. 258-282, 2007.

SMITH, P. Transnacionalismo, bilingüismo y la planeación lingüística en contextos educativos mexicanos. Los Retos de la Política del Lenguaje en el Siglo XXI. v. II. México: Universidad Nacional Autónoma de México, 2006. p. $419-441$.

SMITH, P. H. 'Ni a pocha va a llegar': Minority language loss and a dual language schooling in the US-Mexico borderlands. Southwest Journal of Linguistics, v. 21, n. 1, p. 165-181, 2002.

SMITH, P. H.; MURILLO, L. A. Repositioning biliteracy as a capital for learning: Lessons from teacher preparation at the US-Mexico border. International Journal of Qualitative Studies in Education, v. 26, n. 3, p. 301-323, 2013.

SUÁREZ-OROZCO, C.; SUÁREZ-OROZCO, M. M. Children of immigration. Cambridge, MA: Harvard University Press, 2001.

TAJFEL, H.; TURNER, J. C. The social identity theory of intergroup behavior. In: WORCHEL, S.; AUSTIN, W. G. (Eds.). Psychology of intergroup relations. Chicago: Nelson-Hall, 1986. p. 7-24. 
TANIGUCHI, S. Second language writing as a way of negotiating bilingual identities: Case study of a returnee from China. JALT at Shizuoka, Conference proceedings , p. 36-41, 2002.

TRUEBA, E. T. The new Americans: Immigrants and Transnationals at Work. New York: Rowman \& Littlefield, 2004.

WALDINGER, R. Immigrant transnationalism. Current Sociology Review, v. 6, p. 756-777, 2013.

WEBSTER, L.; MERTOVA, P. Using narrative inquiry as a research method. New York: Routledge, 2007.

WILLIANS, S. L.; ALVAREZ, S. D.; ANDRADE HAUCK, K. S. My name is not María: Young Latinas seeking home in the heartland. Social Problems, v. 49, n. 4, p. 563-584, 2002.

WYMAN, M. Round trip to America: The immigrants return to Europe 1880-1930. Ithaca and London: Cornell University Press, 1993.

ZENTELLA, A. C. Latin@ languages and identities. In: SUÁREZOROZCO, M.; PÁEZ, M. (Eds.). Latinos: Remaking America. Berkeley: University of California Press, 2002. p. 321-338.

Recebido em: 14/05/2015 Aceito: $11 / 11 / 2015$ 